\title{
O espelho equívoco. O núcleo filosófico da Spiegel-Interview a Martin Heidegger
}

\author{
Irene Borges-Duarte
}

É tão habitual considerar a célebre entrevista concedida por Martin Heidegger em 1966 ao semanário alemão Der Spiegel como tendo um interesse fundamentalmente biográfico, que pouco se tem atendido ao seu conteúdo eminentemente filosófico. São, contudo, os grandes temas do pensamento heideggeriano os que afloram nesse fragmento, jornalisticamente concebido. Essa perspectiva, normalmente descuidada nos enfoques desta peça do corpus heideggeriano, é a que este estudo procura tematizar'.

O registo jornalístico foi tomado, oportunamente, pelo próprio director da prestigiosa revista, Rudolph Augstein ${ }^{2}$, que interroga uma personagem, tornada pública por inúmeras polémicas em torno a um passado politicamente incorrecto, em nome de um leitor-modelo que o entrevistador, socialmente, representa. Esse público potencial pretende saber, essencialmente, uma coisa: qual foi o envolvimento de Heidegger com o regime nazi, antes, durante e depois do seu período como Reitor da Universidade de Friburgo. E Heidegger responde a esse interesse de duas

I Na sua versão original, aqui reelaborada, este texto surgiu, há alguns anos, em Madrid, do trabalho lectivo com alunos de um curso de História da Filosofia. A extraordinária força e fecundidade da relação do João Paisana com os seus alunos, sempre centrada na vitalidade do pensamento e na afabilidade do trato, levou-me a escolher esta meditação sobre a relação ontológica e o diálogo em sua homenagem.

Ao Joăo Paisana, humano no mais autêntico dos sentidos, e ao excelente Colega, de cuja paixão fenomenológica e de cujo conselho sentiremos a falta na investigação de "Heidegger em Português", que tão generosamente apoiou.

2 Realizada em 23 de Setembro de $1966 \mathrm{~cm}$ casa de Heidegger, sob a direç̧ão de Rudolph Augstein, director de Der Spiegel, a entrevista só foi publicada postumamente, de acordo com os desejos daquele, em 31 de Maio de 1976. Hermann Heidegger, gestor do legado paterno, deu ao prelo em 1988 uma versão, revista e aprovada pelo entrevistado, anterior àquela que foi efectivamente publicada (in G. NESKE u. E. KETTERING, Hg., Antwort. Martin Heidegger im Gespräch, Pfullingen, Neske, 1988). As alterações relativamente àquela primeira edição não me parecem significativas, mas tive-as em conta na minha tradução anotada da Entrevista: "Já só um Deus nos pode ainda salvar", Filosofía. Publicação da Sociedade Portuguesa de Filosofia (Lisboa), v. III n. 1-2, 1989, 109-135. É essa tradução, às vezes ligeiramente modificada, e a respectiva paginação que se reproduz no presente trabalho. Há outra versão portuguesa mais recente, de J. P. Cabrera, mas feita a partir da tradução francesa do texto da entrevista por Jean Launay e François Fédier e incluida por este último ña sua edição dos É crits politiques, Paris, Gallimard, 1975. 
maneiras: em primeiro lugar, dando alguns dados e informações de tipo biográfico, até então desconhecidos, acerca desse período da sua vida (o que constitui, basicamente, a primeira parte do texto); em segundo lugar, conduzindo as suas respostas a outro tipo de questões, que integram de forma essencial o que poderíamos chamar o "núcleo duro" do seu pensamento filosófico. Se, com o primeiro tipo de respostas, dá uma no cravo e outra na ferradura, oferecendo a "sua" leitura - que nenhuma oposição lhe pode levantar em vida, uma vez que proibe o aparecimento da entrevista durante o tempo que lhe reste (e que vão resultar ser dez anos) - e esquivando certas derivações possíveis; com o segundo tipo de pronunciamentos, não só indica os âmbitos mais investidos que a sua própria interrogação configura, como, simultaneamente, reconduz nessa direç̧ão a maior parte das perguntas interessadas do jornalista, deslocando desse modo o sentido e alcance das questões, que, pouco a pouco, vão perdendo o tino biográfico e a dimensão política. A "entrevista" converte-se, assim, numa nova forma de "diálogo", género literário e filosófico que Heidegger cultivou em vários momentos e de diferentes maneiras. É um caminho estranho, para quem tenha como expectativa de sentido a justificação de atitudes e ditos suspeitos de uma trajectória humana exposta ao juízo ideológico de um post-guerra de vencedores exacerbados e perdedores culpabilizados, mas muito interessante, pelo contrário, para quem esteja atento às questões abordadas, que articulam uma autêntica introdução ao pensamento do entrevistado. O "espelho de uma vida humana", que a entrevista pretendia ser inicialmente, transforma-se, pois, pouco a pouco, a princípio equivocamente, depois decidida e imparavelmente, na resposta do pensar ao desafio ingente da era técnica.

Se excluirmos o fio meramente biográfico, embora sem prescindir do que ele vai permitindo dizer, encontramos os seguintes temas fundamentais: a técnica, questão axial do Heidegger maduro, a que todas as restantes remetem, e que constituirá o primeiro momento da nossa análise, pois é ela que permite compreender quer a dimensão política do pensar e da vida do autor, quer a sua referência em clave aparentemente escatológica ao "deus", para que o título da entrevista aponta; com ela se relacionam, também, as abordagens da arte e da literatura, da língua e da tradução, tocadas na parte final do diálogo; o tema do final da filosofia e do seu desembocar num misterioso outro pensar fecham este quadro conceptual que a questão inicial marcou indelevelmente. É este percurso que vamos, com parcimónia de meios e espaço, seguir.

\section{A TÉCNICA}

Constitui, como já foi anunciado, o tema central da entrevista, para que todos os outros remetem. Heidegger tem uma interpretação singular da «técnica», que considera ser a tendência fundamental do homem moderno e, por isso, o perfil que define a nossa época da modernidade tardia e vigora no momento do «ocaso do Ocidente». Começam por surgir duas concepções diferentes de técnica.

1. A vulgar, defendida pelo entrevistador, e que, noutro escrito, Heidegger designa como «concepção instrumental» da técnica. Consiste em acreditar que «a técnica», porque tem que ver com o uso e manipulação de instrumentos (meios e fins da nossa intervenção eficaz em ordem ao bem-estar pessoal ou social) é ela mesma um instrumento: a nossa ferramenta mais eficaz e mais preciosa. Na medida em que, além do mais, é algo «do homem» (invento e património do homo faber), 
também podemos designá-la como concepção antropológica da técnica ${ }^{3}$. $\mathrm{O}$ entrevistador defende, nesse contexto, que só se pode entender que a técnica constitui um perigo para o homem, na medida em que nunca, "em época nenhuma, o homem dominou os seus instrumentos", tendo-se comportado sempre como um eterno aprendiz de feiticeiro (120).

2. Heidegger, pelo contrário, nega que a técnica seja um instrumento ou que tenha que ver com instrumentos, embora esteja de acordo em que é, sem dúvida, «algo que o homem por si mesmo não domina» (120). O seu perfil desenha-se com uma breve frase: «tudo funciona» (121). Desse modo, Heidegger quer dizer que, apesar da manipulação técnica ter que ver com instrumentos, a essência da técnica não é ela mesma "técnica», mas algo totalmente distinto. Num primeiro momento, diz que, nisso, se manifesta «un poder» (120); depois, que esse poder se dá como uma «com-posição» (122). Esse poder e com-posição revelam uma «capacidade de determinar a história», capacidade que não é, portanto, meramente humana, não só porque se escape das mãos do homem, mas porque esse poder é mais potente que o próprio homem, impondo-se-lhe e decidindo acerca do destino do mundo numa escala planetária. Por isso, é inquietante e sinistro. E é por isso que constitui, para Heidegger, o que há que pensar hoje.

Explicitação deste conceito heideggeriano de «técnica»:

«Vejo a essencia da técnica naquilo a que chamo Ge-Stell (composição) [...] O imperar da com-posição significa que o homem é (com-)posto, solicitado e provocado por um poder, que se manifiesta na essência da técnica» $(122)^{4}$.

O poder que se manifiesta na técnica, mas não é ele mesmo de tipo técnico, consiste numa certa maneira de se impor ao homem, atribuindo-lhe um lugar ou posto e provocando-o a que actue com a correspondente (com)postura, isto é, exigindo que se comporte no mundo, com as coisas e com os outros, de determinado modo: aquele que é requerido pela sua função. O que, assim, acontece é a universalização das «relações meramente técnicas» (121). Que quer isto dizer?

$\mathrm{O}$ homem deseja e procura, com a sua inteligência e o seu saber, alcançar o bem-estar. Graças ao progresso técnico-científico pode disfrutar cada vez mais desse

3 O texto essencial, aqui aludido, é "Die Frage nach der Technik" (1953), in Vorträge und Aufsätze, hoje já acessível na Gesamtausgabe, Vol. 7, Frankfurt, Klostermann, 2000 (ed. De F.-W. Von Herrmann).

4 Introduzo uma ligeira alteração à tradução citada, acentuando o contexto de sentido ligado à palavra-chave (Ge-Stell, com-posição). Uma justificação sistemática desta leitura e tradução é objecto do meu trabalho: "La tesis de Heidegger sobre la técnica", Anales del Seminario de Historia de la Filosofia (Madrid) 10, 1993, 119-154. Sendo um termo etimologicamente marcado pela referência ao "pôr", situante de algo num determinado lugar, ao mesmo tempo que ganha, no seu uso por Heidegger, um sentido metafórico e simbólico, não é fácil encontrar equivalente de Ge-Stell noutra língua, pelo que há versões para todos os gostos, alguns perversos. Outras duas versões possíveis, que atendem a dois dos matizes essenciais a ter em conta no todo de significação, são as de Félix Duque, que traduz por "estructura de emplazamiento", e a de Gianni Vattimo, que prefere "imposizione". François Fédier, num texto teórico em torno à questão da técnica, também propõe "composition". 
melhor nível de vida. Habitua-se a ele e deseja conservá-lo e aumentá-lo cada vez mais. Portanto, incrementa a intervenção técnica a todos os níveis e em todos os campos, racionaliza o seu comportamento individual e social, domestica a natureza e domestica-se a si próprio, pondo tudo ao seu serviço em aras dessa finalidade. Desse modo, aquilo que parecia não ser nada mais que um meio (a técnica) para alcançar um fim (o bem-estar) transforma-se no próprio motor do progresso social e, dessa forma, acaba por se impor ao homem com a pregnância sub-reptícia não tanto de uma ordem, mas de uma evidência: é «o que há que fazer», a «maneira como há que comportar-se». Progredir é, por exemplo, racionalizar o uso das matérias primas, dos meios e sistemas de produção e da mão de obra, enquanto elos necessários da cadeia produtiva. Neste esquema tão simples e óbvio, a relação entre a natureza, o homem e os produtos que este, com o seu trabalho elabora a partir daquela, é «meramente técnica». É, justamente, em virtude desse procedimento que tudo funciona. Para que assim continue a ser, há que reproduzir até ao infinito a relação assim definida. O homem fica encerrado dentro do círculo ou engrenagem determinantes de uma modalidade de compreensão do mundo, de que só pela reflexão poderá distanciar-se. Dificil reflexão, porquanto está habituado a não reparar no «sinistro» desta situação que, normalmente, até considera ser desejável.

Em resumo: Há um poder que se manifiesta na técnica, poder que é tanto mais poderoso quanto mais desapercebido passa. Esse força imanente actua de uma maneira determinada: solicita ao homem que se comporte «tecnicamente». Solicita significa "requer": a título sub-reptício, sugerindo um modo de actuar, e de forma explícita, exigindo uma actuação funcional, de acordo com o posto que se ocupa na grelha social. Em ambos os casos, obriga o homem à compostura para com a situação, em que, mesmo sem dar por isso e sobretudo sem dar por isso, se encontra já chamado ou pro-vocado a actuar segundo as regras do jogo, de que, ontico-positivamente, podem referir-se diferentes instâncias (socio-económicas, político-jurídicas, etc.). O poder da "com-posição" técnica do mundo, que noutros textos Heidegger denominou "constelação" homem-ser, pode, pois, considerar-se um «império»: o imperialismo da configuração técnica do mundo, que define a nossa época.

Dar-se conta desta situação - «fazer a experiência deste estar-(com)posto do homem por algo que não é ele próprio e que ele próprio não domina» $(134$, n. 31$)$ - é abrir a possibilidade de compreender não só o seu sítio, mas também a sua dignidade ontológica como «aí-do-ser». Ser o «aí» significa que o homem serve o ser e o ser se serve do homem, que o homem precisa do ser e «que o ser precisa do homem» como de sua morada e que, portanto, poderá aparecer sob qualquer figura que o homem lhe dê (por ex., a da técnica), sem que por isso se lhe reduza, escapando-se sempre ao aparente controlo humano. Quanto menos desperto se encontrem os humanos para a subtileza desta figura epocal, tanto mais impotentes e próximos do impensado abismo estarão. Se, contudo, despertasse, descubriria, talvez, novas possibilidades de ser e poderia, talvez, inaugurar uma nova época da história-destino do ser no mundo humano.

\section{A POLÍTICA}

Avançada, de entrada, pelos entrevistadores, é com esta questão que começa a entrevista, estendendo-se em peripécias biográficas, durante toda a primeira metade do diálogo (até à pág. 119), que depois desemboca numa abordagem mais teórica. É Heidegger quem, pouco a pouco, vai levando esta temática até a enraizar no solo 
a que, segundo ele, pertence: o «ir ao encontro» da técnica planetária e do homem moderno.

\section{Principais teses defendidas:}

1. Carácter parcial, de «meias tintas» (ou "metades", Halbheiten) de qualquer ideologia política (120). A este respeito, Heidegger mete no mesmo saco o nazismo, o comunismo e até a democracia (liberal ou cristã), numa atitude que defendeu em muitos outros lugares, e foi objecto de muitos ataques ad hominem, basicamente redutíveis ao argumento "depois de casa roubada, trancas à porta". A verdade, porém, é que a razão aduzida é plenamente coerente com as suas teses anteriormente enunciadas: as ideologias e as políticas delas derivadas não só não se enfrentam com o problema da técnica, como, antes pelo contrário, lhe seguem o jogo: estão ao serviço dela. Neste sentido, um «estado absolutamente técnico» seria o esbirro mais fiel do poder da técnica (121-122).

2. De facto, as ideologias políticas mais não fazem senão recolher e reproduzir a concepção vulgar («instrumental») da técnica, numa projecção tecnocrática. Esta concepção subjaz à potencialização institucional da investigação científica, enquanto via de possibilitação da manipulação e organização técnicas (128-129), inerentes à constituição e conservação da sociedade do bem-estar, em que «tudo funciona» e em que «o funcionamento conduz sempre a mais funcionamento» (121). Os êxitos da tecnociência, inegáveis, inesgotáveis, barram o caminho a uma autêntica meditação sobre a essência desse destino, ao torná-la aparentemente "supérflua" (129), tendo em vista os resultados práticos efectivamente alcançados. Obstruído o caminho da reflexão, «já só nos restam relações meramente técnicas» (121).

3. Reconhece, porém, que em 1935 ainda acreditava que no "movimento" nazi havia uma compreensão positiva da essência da técnica enquanto expresão da modernidade (119), segundo a conhecida expressão da Introdução à Metafísica, citada na entrevista. No entanto, a sequência do texto não chega a deixar claro o que é que viu aí que fosse "conforme à era técnica" (120), nem porque é que não se deu conta, então, de que «essa gente era demasiado incapaz de pensar para conseguir estabelecer uma relação realmente explícita» (126) à essência da técnica. O que afirma, inequivocamente, é que "a verdade íntima e a grandeza do movimiento" fracassam facticamente por não chegar a ser compreendida a "grandeza histórica" do poder inerente ao "movimento planetário da técnica moderna" $(119,120)$.

Não é só do ponto de vista biográfico que temos o direito de perguntar-nos por que é que Heidegger acreditou que no nazismo se abria uma tal possibilidade. A questão é mais abrangente que a de uma mera cegueira transitória acerca dessa "mobilização total", de que Ernst Jünger falara já em 1930, e a que o Estado nazi efectivamente correspondia, da menos livre das maneiras. O texto da entrevista não é, certamente, claro nesta matéria, embora ofereça indicações com as quais podemos desenhar uma resposta a título de hipótese:

Heidegger sempre defenderá que «tudo o que é essencial e tem grandeza surgiu do homem ter uma pátria [terra natal, Heimat] e estar enraizado numa tradição» (121). A ideologia "nacional" e "socialista" pareceu-lhe ir nessa linha, uma vez que não aspirava a ser «mera» política, mas um movimento de renovação total e de busca das origens nacionais. Esse «nacionalismo» foi entendido por Heidegger como 
defesa das raízes de um «povo» (língua, tradição) contra o desenraizamento e salto à «escala planetária», que habitava o projecto da modernidade ${ }^{5}$. Contudo, a insuficiência do pensar "dessa gente" tê-los-ia conduzido pela via imperialista e totalitária, pondo justamente em prática a mais refinada técnica de controlo e programação, que Heidegger chegou a definir com o termo Ge-Stell: a utilização sistemática da propaganda como controlo da opinião pública, a criação das figuras sociais (que permitem, entre outras coisas, desenhar o perfil do inimigo interno, que há que perseguir e aniquilar), a utilização da máquina fabril na preparação daquilo que, finalmente, teria de ser a guerra... Gora-se, pois, a primitiva esperança de voltar às raizes - esperança talvez demasiado provinciana e ilusa, do filho do tanoeiro e sacristão, que por volta de 1933 apenas estava empenhado em reformar a universidade, mediante a superação da mera "organização técnica" das faculdades e o pelo "enraizamento das ciências no solo da sua essência" (111) - únicos aspectos para que estivera propriamente desperto.

4. Em qualquer caso, o fracasso da política (da mera política) manifesta a necessidade de que a «renovação» se dê a outro nível: o do "pensar» (fora da esfera do público, do falatório ideológico). Como veremos mais adiante, este pensar é menos de tipo filosófico que «poético» (120) e o que busca é «alcançar o poder da não-violência» (121). Poético significa criativo: «não é inactividade, mas o próprio agir» (125), não é teoria que anteceda e prepare a praxis, mas sim um certo modo de fazer. Este não actua, porém, da maneira directa a que aspira a intervenção política no mundo (a «transformação» revolucionária, a "alteração imediata do estado de coisas", 122), mas antes por via indirecta, distanciada da política: é o agir da reflexão ou meditação acerca do destino-história do mundo. Assim, paradoxalmente, a missão deste pensar - que é a de «contribuir para que o homem chegue a conseguir estabelecer uma relação satisfatória com a essência da técnica» (126) - manifestar-se-á mediante o «despertar» de uma «atitude», não ante a polis mas ante o divino: trata-se de «experimentar a ausência» e «aguardar» «um deus» $(122,123)$.

\section{UMDEUS}

A problemática, surpreendente pelo carácter intempestivo da sua introdução (122), num contexto que era aparentemente político, procede de Heidegger e não das perguntas de quem entrevista. O elemento conector com a questão da política é o fracasso desta ante a «técnica» e a necessidade de «um pensar», que tenha por tarefa alertar o homem para a essência e o poder ocultos da técnica, como forma de preparar uma possível mudança, de contornos bem mais amplos que os propriamente

5 João PAISANA, num texto breve e inteligente, em que analisa justamente a inconsistência do pensamento político de Heidegger, encontra uma extrapolação - infundada mas não "desprovida de pesadas consequências" - dos conceitos ontológicos de Ser e Tempo para o contexto político dos seus discursos de época, "sem autêntico trabalho de reformulação", passando ambiguamente "do nível ontológico de Sein und Zeit e das obras filosóficas de Heidegger, para o nível ôntico, expresso nos discursos e declarações de 1933/34". Se os primeiros "não permitem uma imediata interpretação ética ou política", nos segundos Aao identificar o Dasein com o povo (alemão), o mundo com a pátria (alemã) e ao determinar o trabalho como a relação de um povo com a sua pátria (o solo), não só transpõe insensivelmente do nível ontológico para o ôntico, como vai abordar o nível ôntico em termos exclusivamente ontológicos, ignorando a especificidade desse mesmo nível ôntico. Veja-se PAISANA, J., "A questão política em Heidegger", Vértice, II0 série, n. ${ }^{\circ} 23,1990,35-37$ a 2 col. 
políticos. O horizonte em que Heidegger enquadra o tema do divino é, portanto, igualmente, o do «encontro» com a técnica planetária e com a modernidade.

Tese básica:

Nem a política, nem a filosofia, nem nenhuma acção meramente humana podem operar mudança alguma, de modo imediato, na situação actual, antes cunhada na expressão «relações meramente técnicas». "Já só um deus nos pode ainda salvar ${ }^{6}$ ».

Os problemas que semelhante tese levanta são multíplices, desde os que derivam, uma vez mais, daquilo que a lógica e metafísica tradicionais chamariam uma anfibologia (a deslocação da questão para um âmbito problemático que não é aquele em que originariamente se encontrava, com a consequente inconsequência argumentativa), até aos que são, pura e simplesmente, evidentes. Para já, haveria que explicitar o conteúdo sibilino da afirmação: 1) Um deus? De que é que se está a falar? 2) Salvar? Qưe quer dizer? 3) Só um deus? 4) Já? Ainda? 5) Como??.

\section{1. «Um deus»}

À partida, não se menciona assim nem algo «meramente humano», nem uma «coisa», isto é, algo com carácter de «ente», tal como os há, enquanto algo que se dá, de facto, como algo real e efectivo. O que quer que signifique este "deus" deverá ser totalmente outro: o que não se deixe nomear à maneira dos entes. Isto implica que também não deve ser um "ente divino", sob alguma das diferentes figuras que, historicamente, conhecemos: o Deus cristão ou o maometano, ou o Deus do Antigo Testamento, os deuses da antiguidade clássica ou de qualquer cultura longínqua. Trata-se, pelo contrário, de um deus «ausente», cuja aparição ou advento se trata de preparar (122-123) e que pode ser que não chegue nunca. A única coisa que o homem pode fazer é apenas «preparar-se para estar disposto a manter-se aberto à [sua] chegada ou à [sua] falta» (123), ou seja, perceber a sua necessidade, a urgência de um vínculo ou relação íntima ao que não é ente.

Uma vez que esta referência heideggeriana surge no contexto de um tentar romper o actual estado de coisas - «já só há relações meramente técnicas»-, temos que considerar que a necessidade de um tal deus desconhecido e sem figura, só pode significar, para já, que é preciso que o homem se dê conta de que nem tudo se deixa manipular e instrumentalizar, que há algo que jamais poderá ser compreendido no quadro de uma relação técnica, nem como um meio, nem sequer como um fim visado pelo homem.

Deste ponto de vista, não é importante saber que deus é esse, nem se foi compreendido no passado desta ou daquela maneira, mas sim que qualquer que seja ou tenha sido a sua possivel figura fáctica (para quem quer que queira crer o

6 Em alemão, "Nur noch ein Gott kann uns retten". Como veremos, o sentido do uso heideggeriano do termo, neste preciso contexto, impede que possa ser identificado com o "Deus" judaico-cristão, pelo que a sua grafia correcta deveria ser "deus", fórmula que é empregue aqui, mas que, não sei por que zelo ortográfico, não apareceu no texto publicado na revista Filosofia, cujas provas tipográficas não corrigi.

7 As respostas esboçadas são, uma vez mais, hipóteses interpretativas, cuja plena explicitação implicaria uma amplitude de referências, aqui só liminarmente indicadas. 
não crer naquilo a que a tradição chamou a sua "existência"), o homem de hoje, na fase terminal da modernidade, carece - no duplo sentido de falta e de necessidade - do vínculo com o não-ente, com o que, enquanto ausente, recusa qualquer figura ôntica. Ao fim e ao cabo, uma ligação que, noutros textos, Heidegger quis mostrar plasticamente como correspondendo ao hífen, ao traço de união, entre o ser e o ser aí: Da-sein. Essa ligação é, por outro lado, dupla: o que aqui se sublinha é que o homem precisa do ser, precisa de sentir-se e saber-se ligado ao ser, mas também não se deixa de indicar que "o ser precisa do homem para a sua manifestação, custódia e configuração"(122). Voltaremos a esta questão.

\section{2. «salvar»}

Salvar de quê? Da queda no ente (123), do esquecimento do ser, da rotina do estar perdido entre as muitas coisas que possuímos e constituem os pequenos troféus do nosso quotidiano procurar fazer pela vida. Esta "salvação" - e o uso aqui do termo não se furta, certamente, ao contexto de uso religioso, ao matiz de redenção - menciona a recuperação do vínculo originário, a libertação, pois, relativamente ao automatismo de tomar como medida do que acontece «o cálculo técnico», a mera "relação técnica».

Salvar significa, então, para Heidegger - embora na entrevista este aspecto não surja tão claramente como noutros textos ${ }^{8}$ - "recordar", voltar a pensar o que ficou encoberto e que a nossa maneira habitual e familiar de (não) ver o que nos acontece chega a obstruir. Não se trata, portanto, de uma espécie de "operação de resgate" - actuação, ao fim e ao cabo, "técnica" - pela qual "um deus" nos tire dos apuros em que, hábeis mas ávidos aprendizes de todos os feitiços, nos metemos. Isso seria ainda permanecer dentro da "relação meramente técnica", meter o deus no nosso processo de salvação pessoal e colectiva, como quem olha por nós, condescendente e amigo. Isso seria conceber o deus como o "bruxo" ou feiticeiro omnipotente (o "impulso exterior", 123) que, ao voltar a casa "salva" in extremis o pobre aprendiz dos desmandos de uma técnica carente da força "mágica" do autêntico poder fazer. Seria recorrer, afinal, ao velho truque do deus ex machina, permanecendo na concepção antropológica e instrumental da técnica.

\section{3. «só um deus...»}

Que pode querer isto dizer senão que tem mesmo que haver um deus, sem o qual o homem não poderá conseguir libertar-se do seu próprio imparável feitiço? Contudo, a possível resposta de Heidegger não fala propriamente do deus, mas do - «ser»:

«O mundo não pode ser aquilo que é e tal como é mediante o homem, mas também não pode sê-lo sem ele. [...] é justamente ao fazer a experiência deste ser (com)posto do homem por algo que não é ele próprio e que ele próprio não domina, que se lhe mostra

8 Veja-se, fundamentalmente, o final de "Die Frage nach der Technik", ed. cit., 29 seg.; "Wozu Dichter", in Holzwege, Gesamtausgabe Vol. 5, 296 seg. (trad. pt. de B. Sylla e V. Moura:

"Para quê poetas?", in Caminhos de Floresta, Lisboa Gulbenkian, 2002, 340 seg.). 
a possibilidade de compreender que o homem é usado [gebraucht] pelo ser" $(134$, n. 31$)$, "que o ser precisa [braucht] do homem para a sua manifestação, custódia e configuração» (122).

Ou seja: que o homem seja o ai-ser (aí-do-ser) significa que o ser só aí (na edificação compreensiva do sentido no mundo humano) acede a mostrar-se. Para se «mostrar» precisa do homem e usa-o - a dupla significação do alemão brauchen - para chegar ao não-estar-encoberto da verdade, para chegar à obra e à palavra. Mas, ao mostrar-se aí, o «ser» conforma-se com ser visto de uma ou outra maneiras, segundo as culturas e as épocas. Hoje, no nosso orbe planetário, é visto fundamentalmente como algo que se deixa utilizar e manipular, algo sobre que o homem tem controlo. Acomodado a esse «ser" domesticado, o homem esquece-se de que o ser é muito mais que algo domesticável. E, ao esquecer-se da dimensão autêntica e poderosa do ser (dimensão que nunca fica totalmente a descoberto, pois o ser, sendo o que se dá, é também, no mesmo instante, o que se encobre-a-letheia), corre o risco absoluto de se des-ligar, des-vincular, des-enraizar do que constitui a sua própria essência como Da-sein: deixar que o ser se manifeste por si mesmo, deixar-ser.

Assim, também o homem precisa do ser: precisa, em primeiro lugar, de ser, no sentido mais imediato do estar facticamente aí, existir, na sua acepção vulgar, ôntica; precisa, além disso, que o ser se lhe ofereça à compreensão, se lhe apresente em qualquer das suas multíplices formas; precisa, finalmente, de notar que o ser se lhe escapa, quer porque a ausência se lhe impõe na morte, no sem-sentido, quer porque, então, se apercebe de que algo nos entes excede o ente, excedência que marca uma "diferença ontológica". Fazer a experiência disto - de que o homem, para exercer o seu ser, tem que dar por suposto que «há ser» e não meramente este ou aquele «ente» - é recordar a dimensão mais originária do ser: o seu brotar, o seu puro acontecer, que os gregos chamavam physis e compreendiam como uma força habitada e animada pelos deuses. Ora, habitualmente, o homem não repara nisso. No seu quotidiano fazer-a-sua-vida limita-se a fazer uso do que tem à-mão, sem prestar atenção. $\mathrm{O}$ hábito cria o véu que nos desliga da experiência originária do dar-se do ser. Apenas vemos os entes, na sua presença e utilidade, e calculamos como manipulá-los para que resulte bem aquilo que pretendemos fazer, individual ou colectivamente. A luz que habitualmente ilumina a nossa noite não é a do raio de Zeus, tão brutal e assustador quanto deslumbrante, mas a da eficácia anónima de um vulgar interruptor caseiro. E fácil e cómodo o relacionar-se «técnico» com os entes, socialmente pré-programado. Esquecemos, porém, não só que os entes não são meros utensílios, mas também que a nossa relação com eles é um poder, uma dinâmica caracteristicamente humana, pela que se dá forma e, conformando, se deforma o ser de todo o ente na sua originaridade, incluso o ser do homem.

A figura do divino tem representado até hoje, sob qualquer das suas formas culturais, aquilo que, justamente, sempre escapa ao jugo do homo-faber, senhor da terra. Por isso, só o dar-se conta da necesidade de um deus pode ainda «salvar» o homem do afundamento no abismo sem-fundo da aparente vitória sobre todas as coisas. Não é o deus que é salvador, é só a sua recordação, enquanto algo indómito, que justamente não está ao nosso serviço, nem sequer para salvar-nos, mediante qualquer "técnica" redentora. Compreender esse total alheamento daquilo que controlamos é só o que pode, apesar das aparências, da instrumentalização universal do real, compreender a precaridade dessa relação. Só a memória íntima, o anelo do radicalmente não humano - apesar de se manifestar através do mundo humano - pode fazer que este desperte do seu mero e quotidiano fazer-pela-vida, 
confiado nas benesses da civilização do bem-estar. Não é, pois, Deus ou o deus quem "salva", mas sim a saudade da ligação.

\section{4. "Já... ainda"}

Expressôes de tempo, assinalam a profundidade da queda, na aproximação do instante de autenticidade e decisão capaz da reviravolta, que só a própria constelação técnica, na sua essência jânica, pode propiciar. "Já" não é sinal de desistência de qualquer acção, não indica abandono nem desespero. "Ainda" não é marca de esperança. Na sua conexão interna, o "já-ainda" - que traduz o carácter temporal do nur noch - é o projecto de futuro de um "já só", em que o que ainda está a ser se assume como radical histórico: é o momento terminal, espraindo-se no tédio do bem-estar, que permite o pressentir fugaz do Perigo e, assim, uma réstea do acontecimento originário, Ereignis ${ }^{9}$, pelo que se propicia a mútua apropriação do ser e do homem: o acontecer do vínculo que define o Da-sein. Em 1966, date define o Da-sein. Em 1966, dat acção subtil - é o da serena apropriação do sido: a recordação da origem. Já, ainda: os advérbios da saudade.

\section{Como recuperar o vínculo salvador?}

Uma vez mais, Heidegger muda de tom. Não é a "religião", cada uma com a sua Igreja, nem a "filosofia» à maneira tradicional que pode proporcionar essa recuperação. É um «outro pensar» (124). A impaciência comedida do entrevistador, a esse propósito, denota a estranheza da expressão. Deixaremos para o final esta questão, limitando-nos, por agora, a assinalar no seu contexto próprio, que para Heidegger esta acção do pensar não tem os contornos redentores de qualquer das religiões fácticas - a breve referência ao budismo zen permite-lhe desconectar a possibilidade de salvação pelo salto a essa via, cujas raizes culturais são alheias ao Ocidente $(124,127)$ - nem muito menos de qualquer possível ideologia política, limitando-se a consistir numa «reflexão sobre o que hoje acontece» (123). Nessa medida, tratar-se-á de "fazer a experiência da falta» (isto é: da ausência do deus) e, portanto, em «preparar a sua chegada». Este movimento revelador (da presença ou da falta) também se deverá mostrar-se na arte e na literatura.

\section{ARTE ELITERATURA}

Nenhum dos temas é central na entrevista, aparecendo só de forma marginal, em ambos os casos a propósito do seu carácter hipoteticamente "destrutivo» na actualidade $(121,129)$. Heidegger parece afirmar tal carácter, o entrevistador manifesta a sua discrepância. A palavra-chave, que há que entender no seu contexto, é pois, «destrutivo». Vejamos.

Heidegger dá como exemplo de desenraizamento - em resposta a uma pergunta do entrevistador, que se interrogava acerca de se seria missão do homem o "estar

9 Ver ainda "Die Frage nach der Technik", 33-36; Identität und Diferenz, Pfullingen, Neske, 1957, 23 seg. 
nesta terra" - a literatura contemporânea, que considera "destrutiva". Estamos, certamente, longe do sentido do termo na primeira época do pensamento do autor, em que Destruktion significava um momento metódico de análise das estruturas categoriais da tradição filosófica. Mas também não podemos ententer o termo em sentido «niilista», uma vez que Heidegger nega essa possibilidade (121), orientando-nos noutra direcção. Para ele, como já vimos, é essencial o "ter raízes" na terra pátria, na tradição, não cortá-las. Ora, a literatura actual expressa bem a universalidade da civilização planetária, a ruptura do vínculo com uma tradição histórica. Nos antípodas desta situação, estava a poesia de Hölderlin, que recolhendo as raízes "germânicas», lembrava as origens helénicas da cultura ocidental, desenhando uma relação histórica, pela qual a recordação do passado «indica o futuro» e, assim, «aguarda o deus» (126). O contraste entre os dois momentos a origem e o destino de um movimento histórico - ganha sentido na visualização do traço que, implicitamente, os une e só no mais poeta entre os poetas se revela plenamente: Hölderlin.

No que se refere à Arte, tema investido do pensamento heideggeriano e, provavelmente por isso, chamado à baila pelo responsável de Der Spiegel, Heidegger parte do princípio de que, tal como no que se refere ao pensar, não "há proposições de autoridade" (129), nem carácter normativo. As correntes artísticas actuais manifestam isto sobremaneira, mas não é isso que pode ser classificado de «destrutivo». A que atribui, então, essa característica? A resposta obriga-o, uma vez mais, a deslocar o centro de sentido da pergunta para uma outra interrogação: que lugar ocupa, hoje, a Arte? Ou, dito de outro modo: o que é a Arte actual considera que lhe é mais próprio, o que é que ela procura? (129). A resposta, mais sugerida que explícita, leva Heidegger a enquadrar a Arte actual no esquema tecnológico do mundo: o seu "sítio" actual é o dos "assuntos culturais" ou "empresa cultural", dentro do Estado técnico da civilização industrial (130). Este sítio não é, manifestamente, o da sua origem "piedosa"10 (na arte grega), tendo passado a ser encenação de um teatro social, definição de um espaço novo - o "museu", a exposição - que destrói o sentido originário. Este lugar tem contornos socioeconómicos: é o resultado da provocação técnica, como com-posição e imposição de um certo tipo de comportamento dentro da engrenagem da sociedade de consumo e do bem-estar. A célebre conferência de Atenas ${ }^{11}$, de Maio de 1967, dará continuidade a este quadro, aqui embrionariamente traçado e deixado em aberto, unindo "a proveniência da Arte" e a "determinação do pensar"”.

\section{LÍNGUA/TRADUÇÃO}

Mais uma questão que, sem ser central, ocupa um lugar relevante na entrevista (126-128), tendo como contexto a meditação poética de Hölderlin sobre «o alemão». Relaciona-se, portanto, com a questão da poesia e com a das raízes na terra e

10 Ver, de novo, "Die Frage nach der Technik", 35: ! "E a Arte chamava-se tão só $\varepsilon \dot{\chi} \nu \eta$. [...] Era

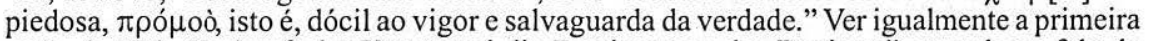
parte de "Die Herkunft der Kunst und die Bestimmung des Denkens", quando se fala da relação da deusa Atena a todo o tipo de arte ou técnica humana (in Denkerfahrungen, Frankfurt, Klostermann. 1983, 136-139)

11 Ver "Die Herkunft der Kunst und die Bestimmung des Denkens", ed. cit.; na minha trad. em castelhano: "La proveniencia del Arte y la determinación del pensamiento", Er-Revista de Filosofia (Sevilla), 15, 1992, 171-187. 
tradição cultural própria, pelo que não aparece como uma reflexão genérica sobre a linguagem, e sim sobre a língua fáctica, com o seu carácter idiomático.

Sabemos, contudo, que o discurso ou fala [Rede], enquanto estrutura existenciária, constituía, em Ser e Tempo, enquanto articulação do projecto compreensivo, o "fundamento ontológico-existenciário da linguagem"12. O homem é o ai-ser, porque na sua comprensão afectiva e inteligente acolhe o ser na palavra. Por isso, na célebre carta a Beaufret de 1946, Heidegger chegará a dizer, numa das suas expressões mais citadas, que "a linguagem é a casa do ser"13. Essa morada tem a sua forma mais pregnante e harmónica na poesia, que é o dizer ontológico por excelência, a forma mais pura e mais própria como o ser se deixa ver na palavra. Mas o poetizar, enquanto projecto linguisticamente articulado, é já sempre, em qualquer caso, um geworfene Entwurf geohistoricamente, isto é, idiomaticamente enraizado.

No idioma ou língua fáctica, o «ser» chega à palavra de uma forma concreta, culturalmente determinada, imersa numa tradição ou forma de comprender de $u m$ povo histórico. Isso condiciona as possibilidades de traduzir - trasladar, transpor ${ }^{14}$ - de uma língua (= uma maneira de entender) a outra (= outra maneira de entender). As dificuldades incrementam-se quanto maior for a carga de pensamento (autoapropriação compreensiva) que habite uma manifestação linguística.

Assim, os enunciados científicos, essencialmente matemáticos, não apresentam dificuldades de tradução (128). A ciência «não pensa» - segundo a fórmula brutal de Que significa pensar ${ }^{15}$-, apenas calcula. O cálculo é meta-idiomático: exprime-se na linguagem "abstracta" dos números, variáveis e equações. Em contrapartida, a filosofia e a poesia manifestam a maneira singular como um povo, numa determinada época histórica e mediante um uso concreto do idioma, dá voz a um desvelar-se do ser. Em cada palavra vem à luz todo um mundo. Por isso, é tão perigosa a missão do tradutor: ao traduzir, até mesmo e sobretudo da forma mais inócua, como parece ser a técnica de "traduzir à letra" (127), está-se a veicular, ao mesmo tempo, dois mundos: o do texto a traduzir e o do próprio tradutor. Traduzir significa sempre interpretar de uma certa maneira. Traduzir significa, além do mais, transmitir e legar a outros essa compreensão. Se atendermos à dimensão imediatamente histórica de tão singular tarefa, toda a tradução é inicio de uma "tradição".

A nossa civilização ocidental nasceu, segundo Heidegger, da tradução do pensamento grego pela mentalidade romana, expressa em latim, e da expansão da tradição greco-latina, surgida desta assimilação e diáspora, com a extensão do império por todo o solo europeu e, finalmente, hoje, por todo o planeta. Desta maneira permanecemos vinculados ao pensamento grego originário, mas não na forma originária, perdida nos confins de uma memória diluida em tantas águas. O nosso vínculo à origem esbate-se e desvirtua-se pelas metamorfoses sofridas por via das traduções de traduções.

12 Ver Sein und Zeit, Vol. 34, Gesamtausgabe 2, 1977.

13 "Brief über den «Humanismus»", in Wegmarken, Gesamtausgabe $9,{ }^{2}$ 1996. Mas a expressão aparece igualmente em "Wozu Dichter", texto do mesmo ano (trad. pt., 356).

14 As citações podiam multiplicar-se. Baste-nos uma referência essencial; "Der Spruch des Anaximander", in Holzwege, $320 \mathrm{seg}$. (trad. pt de J. Constâncio, "O dito de Anaximandro", in Caminhos de floresta, ed. cit., 371 seg.).

is Was heisst Denken?, Tübingen, Niemeyer, 1954, pág. 4. Também aparece no texto curto com o mesmo título e procedência, incluído em Vorträge und Aufsätze, ed. cit., 133. 
Heidegger atribui, neste contexto, uma relevância especial à lingua alemã, para a expressão do pensamento, não porque esteja, como sugeria Leibniz, próxima da adâmica, mas porque a crê, na sua estrutura ou lógica interna, especialmente afim com a grega, idioma da origem da filosofia (127). Está, em contrapartida, convencido que o francês - enquanto expressão de um povo que procurou na máxima racionalidade cartesiana o cume do seu pensar, dando a palavra à nossa modernidade - é uma língua (latina) pouco capacitada para dar voz à riqueza das manifestações do ser, tantas vezes osbcuras e misteriosas, irredutíveis a uma linguagem estritamente «racional» e, por isso mesmo, técnica. Mas a linguagem cartesiana não é a língua dos poetas e dos artistas... e Heidegger não a confunde, certamente, com a palavra de René Char, recordado num momento importante da entrevista (121), nem de Georges Braque, por exemplo, que em 1959 o felicitara com as palavras "L'Echo répond à l'Echo. Tout se répercute"16 $\ldots$

\section{O PENSAR E A FILOSOFIA}

O interesse do entrevistador pelo que poderíamos chamar a «função social» do filósofo atravessa todo o diálogo, constituindo certamente uma das suas pedras angulares. Contudo, as respostas de Heidegger parecem evitar esse enquadramento da questão, sem contudo deixar de lhe dar uma resposta indirecta, em dois momentos;

\section{O tempo da Filosofia.}

Segundo Heidegger, a Filosofia é uma forma temporalmente determinada de pensar. Nasceu na Grécia, desenrolou-se no mundo ocidental e com ele chegou ao fim, na época da tecnologia planetária, que aspira a controlar o futuro, programando-o. A história da filosofia está ligada à expansão e conquista científica (físico-matemática e jurídica) do mundo na Modernidade. Na actualidade, com a dispersão dos saberes, devido à especialização, e com a opção social pelo Direito positivo, que se sobrepõe ao apriorismo do Direito Natural, com a desintegração da própria filosofia - do pouco saber unificado que ainda lhe restava: "Psicologia, a Lógica, a Politologia"... (123) - perdeu a função de unidade que tinha mantido até ao século XIX e a que o positivismo, lendo a situação, a tinha reduzido. Terminou, assim, a sua função de «autoridade», pelo que deixou de poder ser legítimo princípio de qualquer acção. Esta função social, que pertenceu à filosofia moderna, é hoje, segundo Heidegger, apanágio de uma nova ciência: a Cibernética (123). Esta ciência tem por objecto o controlo e a organização das estruturas complexas, quer no ser vivo, quer na máquina. Graças às novas descobertas, a filosofia, que estudava a estrutura do saber em geral (que se manifestava nas diversas ciências particulares) passa a ser algo supérfluo, pois a Cibernética não só permite entender tal estrutura, como também descobrir o rumo adequado a dar à investigação em todos os âmbitos, em função do desejado progresso social. "A filosofia chega ao seu fim» (122). "Terminou" (124). Já não há, portanto, nenhum pensador que "esteja em condições de perscrutar, pelo pensamento, o mundo na sua totalidade, de forma a poder dar orientações práticas" (128). 


\section{A transição para um «outro pensar»}

Mas o final da Filosofla (o fim da Modernidade) não é, para Heidegger, senão o começo do que chama «o outro pensar» (124). Este não pretende continuar nem suprimir a filosofia, mas superá-la, em sentido hegeliano (127), para dar início a outra coisa totalmente distinta.

A missão que, globalmente, lhe corresponde vem enunciada com brevidade: "contribuir, dentro dos seus limites, para que o homem chegue a conseguir estabelecer uma relação suficientemente rica com a essência da técnica» (126). Reconhecendo a sua "provisoriedade e insignificância» - em resposta à "superpotência planetária da essência impensada da técnica moderna" (125) -, renunciando a qualquer ilusão de uma intervenção directa e revolucionária, transformadora da realidade, o pensar nem por isso se coloca numa atitude "passiva»" ou de inactividade: "ele é o próprio agir que, em si mesmo, está em diálogo com o destino do mundo" (125). Essa acção em diálogo com o que está a ser é, para Heidegger, a única possibilidade de despertar uma atitude nova ante a tendência dominante nos nossos dias: aquela que noutros textos denominou serenidade ${ }^{17}$. Nesse suposto, a tarefa a levar a cabo pelo pensar é, portanto, dupla:

1) A reflexão sobre a história ou destino do Ocidente, mediante o diálogo controverso ou confronto com os grandes pensadores (124) da tradição filosófica, cujas obras reflectiram e transmitiram o modo de comprensão do ser que caracteriza o mundo ocidental. Recordando (= salvando) essa tradição no que tem de essencial (os momentos culminantes), torna-se possível reconhecer o que ela não foi capaz de pensar e, assim, abrir-se a pensar o impensado ${ }^{18}$. É nisso que consiste, para Heidegger, a "superação" da filosofía. O que se descobre é que a filosofia, desde Platão, teve sempre em vista os entes e se esqueceu do ser (que é, mas não "existe", mostrando-se sobretudo como "ausência").

2) Preparado por esta reflexão sobre a história, o pensador capacita-se para ver o que está a acontecer hoje e, portanto, para descobrir o que é preciso descobrir. «Ajudar a que isto chegue a ser compreendido» - que a essência do homem é ser-o-aí, servir de morada ao ser, acolhendo-o na sua chegada. - conduz a uma atitude nova: a do aguardar sereno (sem desejo nem expectação, sem vontade de intervenção violenta) do que ainda não adveio. A sua vinda só será percebida por quem aguarda, por quem notou a sua ausência. E essa é a acção possível do "outro pensar": "manter-se aberto para a chegada ou a falta do deus» (123). «... não se pode pedir mais do pensar» (122).

17 Mais que o conhecido texto da conferência com esse nome, Gelassenheit, primeiro do livrinho publicado com esse título (Pfullingen, Neske, 1959), interessa-nos a fundamentaçõo do mesmo, que aparece em forma dialogal no mesmo volume, sob o título "Zur Erörterung der Gelassenheit", mas que constitui um fragmento do primeiro dos Feldweg-Gespräche, Gesamtausgabe 77, 1995.

18 Ver Beiträge zur Philosophie. Vom Ereignis, Gesamtausgabe 65, 1989. É a obra em que o encontro das duas leituras, como de dois inícios da história do ser, se constitui em momento de passagem ao salto recuperador da origem que termina, enquanto abertura pensante ao deus em falta, preparando o vir dos vindouros. Este texto, redigido entre 1936 e 1938, está certamente implícito nas respostas mais investidas de Heidegger nesta entrevista. 


\section{Concluindo:}

O nosso comentário dos temas não biográficos, consentidos ou introduzidos na conversa pelo próprio Heidegger manifesta que eles se estruturam com uma clara intencionalidade, que responde a algo que também interessava o entrevistador, embora de diferente maneira. Tratou de desenhar os contornos do que pode ser a acção do pensar, após ter averiguado o que é que, hoje, há que pensar. Fê-lo praticando a velha arte do diálogo, de uma nova maneira: em vez de ser a pergunta a orientar a resposta num sentido ascendente, à maneira platónica, foram as respostas que, desviando o sentido da interrogação para outro âmbito, mostraram a equivocidade da questão colocada e usaram o espelho da entrevista para mostrar a imagem dúplice da verdade interpretada, em que o ser habita.

Por um lado, o pensamento de Heidegger, nas suas diversas facetas, manifestou ser conservador: almeja recuperar e guardar o vínculo com a origem (a terra, a língua, o divino...), um "passo atrás", partindo do mundo tecnologicamente desenhado à escala planetária e em directa relação com ele. Uma aspiração que hoje, contudo, poderíamos designar como "ecologista" e "anti-globalização" e teríamos dificuldade em decidir se deve ser classificada ideologicamente como "reaccionária" ou "progressista". Por outro lado, porém, disse-nos outra coisa: que é preciso "outro pensar", que prepare poiético-ontologicamente a serena possibilidade de uma reviravolta ôntica, de uma outra modalidade de relação quotidiana homem-ser.

Espelho equívoco, este texto, que as circunstâncias tornaram numa espécie de testamento filosófico, merece ser lido com o olhar que busca o essencial no meio do episódico: a fragilidade ôntica do vínculo ontológico que liga e define o homem e o ser. 
. 